\title{
THE EFFECT OF BIOMATERIAL SELECTION ON THE STATIC STRENGTH OF FEMUR PROSTHESIS
}

\author{
Saim KURAL, Safiye IPEK AYVAZ
}

\begin{abstract}
Throughout the history, biomaterials have been widely used for replacing damaged human organs. Biocompatibility is generally defined as the harmony of the biomaterials with human body physically, chemically and biologically. Mechanical strength properties are of great importance in biocompatibility of the biomaterials which are used as orthosis and prosthesis in skeletal system. In this study, static analyses of femur implants which were modelled by using 316 stainless steel and Ti6Al4V titanium alloy, were carried out under three different axial forces $(500,750$ and $1000 \mathrm{~N})$. As a result of the analyses made, the effect of material selection on the biomechanical and biocompatibility properties of femoral implants was determined.
\end{abstract}

Keywords: biocompatibility; biomaterials; biomechanical; femur Implant; Finite Element Analysis

\section{INTRODUCTION}

Some of the innate causes or the resulting health problems may result in the loss of the function of human living tissues and organs, partially or completely. To recover the lost functions, the living tissues are replaced with implanted materials called biomaterial [1]. Biocompatibility includes definitions of the biocompatibility of implanted biomaterials with respect to their mechanical, physical, and chemical properties, and biocompatibility to surrounding tissues [2]. Biocompatibility of biomaterials is determined by many test results.

The human body has $\mathrm{pH}$ values ranging from 1 to 9 . Therefore, the material to be used should not be exposed to corrosion by surrounding tissues and body fluids. If biomaterials are corroded or physically eroded, biomaterial breakdown particles can pass into human plasma, causing significant health problems such as ulcers, anemia and even Alzheimer's disease [3]. It is therefore important that the chemical and physical abrasion resistance of the material is well defined [3-6]. In addition, the biomaterial used should not have toxic effects on or cause infection of the living tissue around it and should not adversely affect vital activities of the tissue. To determine this biocompatibility feature, invitro tests are used to examine the effect of biomaterials on vital activities of prepared cell cultures. Another method used is in-vivo testing of biomaterials implanted in guinea pigs [7, 8].

The human femur thighbone is the heaviest, longest, and most durable bone in the human body $[9,10]$. Femur fractures are a common occurrence. In the United States alone, 6.5 million people are reported to have broken or injured their femur because of traffic accidents every year. [11]. Mechanical strengths and designs are especially important in the biocompatibility of implants used in skeletal systems such as femur prosthesis. The inclination angle between the head and the body of the prosthesis is especially important in the design of the femoral prosthesis. In some studies, the effect of the angle on the static strength of the prosthesis has been investigated. However, it is known that Coxa Valga occurs when the natural inclination angle of the femur bone is about $130^{\circ}$ and the angle is larger than $130^{\circ}$, while Coxa Vara disorders occur when it is smaller [12-14].

Studies show that most of the human weight is carried by the femurs and that the load applied to the femurs is increasing by walking and running $[9,15]$. The mechanical strength of the prosthetic material used to carry these loads must be good. The most commonly used metallic biomaterials in femurs and other skeletal system implant applications are $\mathrm{CoCr}$ alloys, 316 stainless steel alloys and Ti6A14V titanium alloys [16-19].

In this study, the biomechanical biocompatibility of the femoral prosthesis modeled using 316 stainless steel and Ti6Al4V titanium alloy under different patient weight conditions $(500,750$ and $1000 \mathrm{~N})$ was evaluated and determined.

\section{MODELING AND FINITE ELEMENT ANALYSIS}

In this study, mechanical behaviors of human femoral prosthesis patients at different weights were examined by modelling with ANSYS $₫$ software using 500, 750 and 1000 $\mathrm{N}$ loads. 316L stainless steel alloy and Ti6Al4V titanium alloy, the physical and mechanical properties of which are shown in Tab. 1, were selected as femoral prosthesis materials.

Table 1 Physical and mechanical properties of Ti6al $4 \mathrm{v}$ and $316 \mathrm{l}$ alloys

\begin{tabular}{|c|c|c|c|c|}
\hline Material & $\begin{array}{c}\text { Density } \\
\left(\mathrm{kg} / \mathrm{m}^{3}\right)\end{array}$ & $\begin{array}{c}\text { Poisson } \\
\text { ratio }\end{array}$ & $\begin{array}{c}\text { Elasticity module } \\
(\mathrm{GPa})\end{array}$ & $\begin{array}{c}\text { Yield strength } \\
(\mathrm{MPa})\end{array}$ \\
\hline Ti6Al4V & 4.43 & 0.342 & 114 & 883 \\
\hline 316L & 7.99 & 0.33 & 200 & 300 \\
\hline
\end{tabular}

Fig. 1 shows the geometry and mesh structure of the prosthesis analyzed. In the femoral prosthesis, the mesh structure is thinned by applying a regional mesh to the head and neck which is critical to the load angle. In total 199,196 nodes and 131,665 elements were used. Supported boundary conditions are entered by applying "fixed support" to the 
body part of the prosthesis in the bone. 500, 750 and $1000 \mathrm{~N}$ loads were applied to the head of the prosthesis in contact with the pelvic bone (Fig. 2). As a result of static analysis, total deformation and Von-Mises equivalent stresses were determined and evaluated.

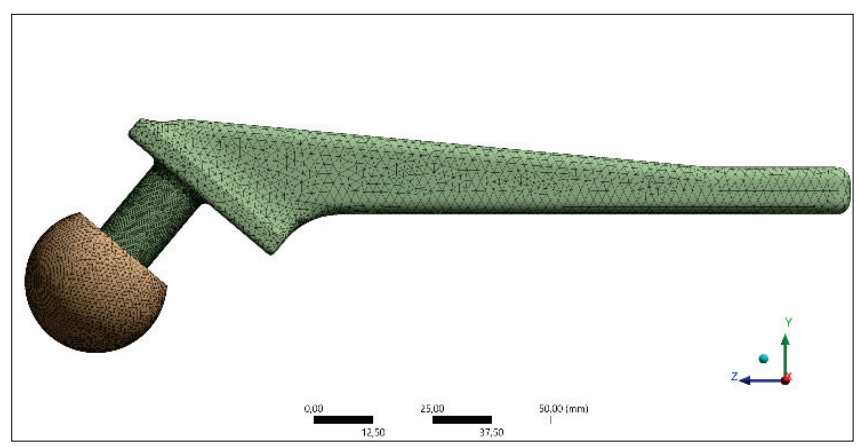

Figure 1 Geometry and mesh structure of femur prosthesis

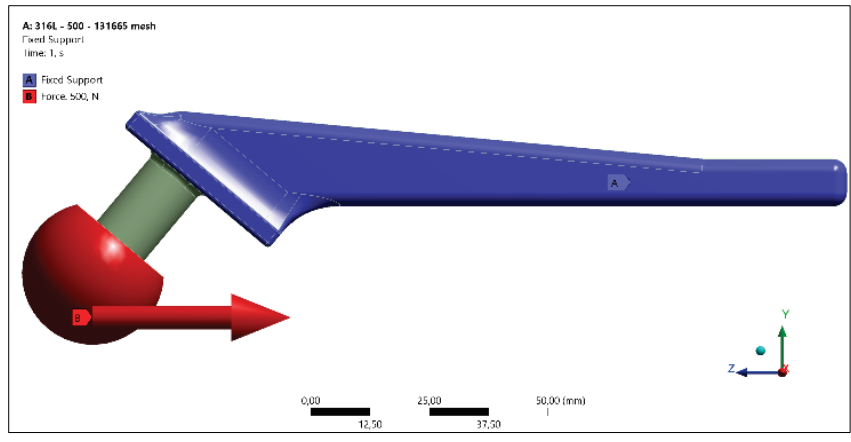

Figure 2 Loads and boundary conditions applied to geometry

\section{RESULTS}

In Fig. 3 and 4, Von-Mises equivalent stresses and total deformations occurring under 500, 750 and $1000 \mathrm{~N}$ loads are given for femoral prosthesis made of $316 \mathrm{~L}$ stainless steel alloy material. The maximum stresses on the prosthesis were seen in the regions where the neck and body parts joined. When the stress analysis results and total deformation data are examined together, it can be seen that the greatest strain change due to stress is in the region where stress is greatest, that is, the region where the prosthesis neck and body join. The maximum total deformation occurs at the head of the prosthesis. The highest total deformation and tensile strengths were observed in prostheses for $1000 \mathrm{~N}$ load, as $0.049329 \mathrm{~mm}$ and $174.05 \mathrm{MPa}$, respectively.

In Fig. 5 and Fig. 6, Von-Mises equivalent stresses and total deformations occurring under 500,750 and $1000 \mathrm{~N}$ loads are given for femoral prosthesis made of Ti6Al4V material. Under the load of $1000 \mathrm{~N}$, a total deformation obtained as $0.086237 \mathrm{~mm}$ and an equivalent stress obtained as $174.05 \mathrm{MPa}$. Under $750 \mathrm{~N}$ load, $0.064678 \mathrm{~mm}$ total deformation and 130.24 MPa equivalent stress, and under a load of $500 \mathrm{~N}, 0.043118 \mathrm{~mm}$ total deformation, $86.25 \mathrm{MPa}$ equivalent stress occurred. The greatest displacement occurs at the head of the prosthesis, the greatest deformation and the greatest stress, in the regions where the prosthesis body and neck join.
Fig. 7 shows the safety coefficients calculated for yield strength of 316L stainless steel alloy and Ti6Al4V titanium alloy femoral prosthesis. Although the deformations and displacements in the Ti6Al4V alloy prosthesis are larger, the safety factors under different loads have been determined to be significantly higher than those of the $316 \mathrm{~L}$ stainless steel prosthesis. The static safety coefficient of the $316 \mathrm{~L}$ stainless steel prosthesis under the $1000 \mathrm{~N}$ load drops below $2(\sim 1.72)$. It will be understood that this prosthesis has a safety factor that is small enough to cause an undesirable situation in terms of human health when it is thought to be exposed to different dynamic loads, twists and shrinks during the vital activities of an overweight patient. This result shows that the $316 \mathrm{~L}$ stainless steel alloy is mechanically biodegradable as a femoral prosthetic material for overweight patients.

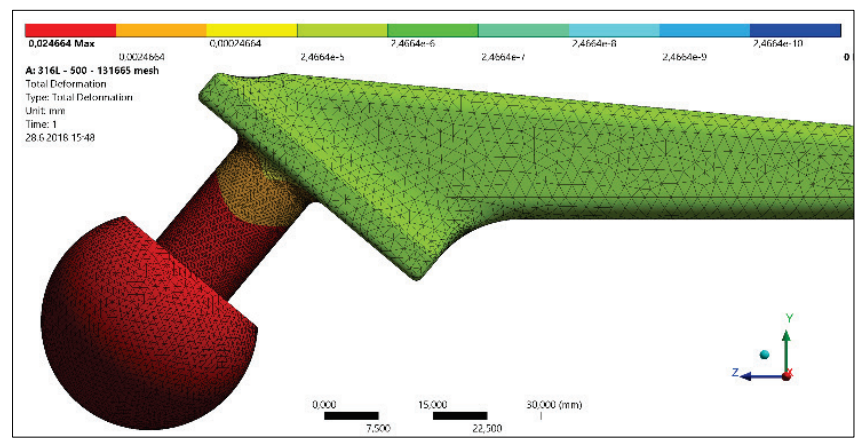

(a)

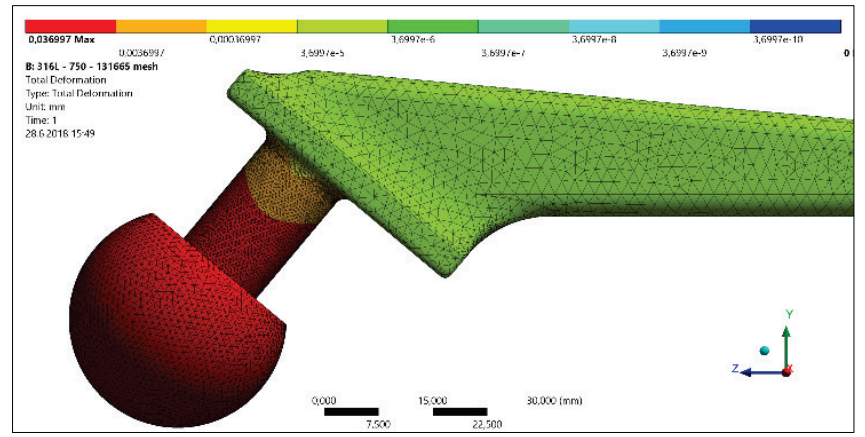

(b)

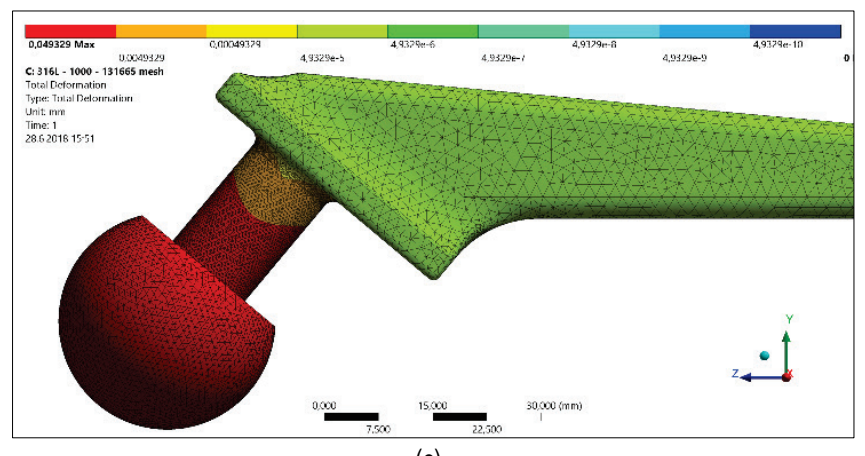

(c)

Figure 3 Total deformations under (a) $500 \mathrm{~N}$, (b) $750 \mathrm{~N}$, and (c) $1000 \mathrm{~N}$ loads on $316 \mathrm{~L}$ femur prosthesis 


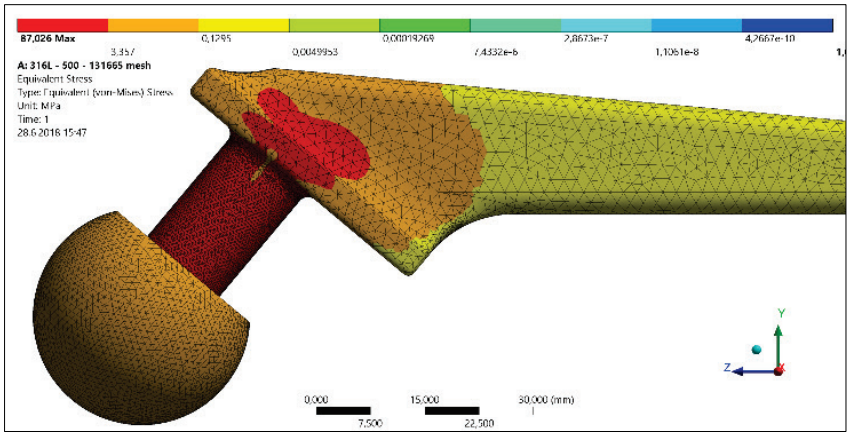

(a)

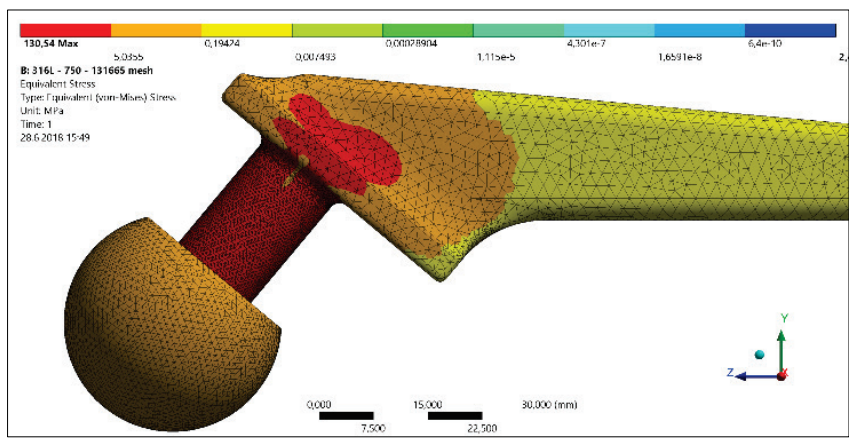

(b)

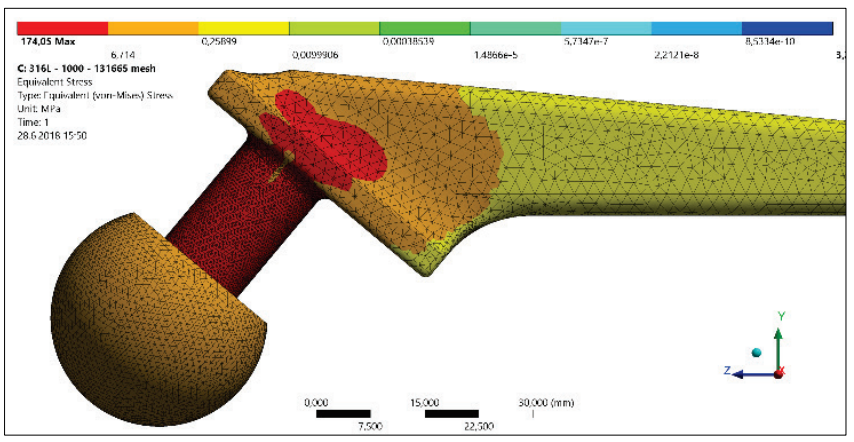

(c)

Figure 4 Equivalent stresses under (a) $500 \mathrm{~N}$, (b) $750 \mathrm{~N}$, and (c) $1000 \mathrm{~N}$ loads on $316 \mathrm{~L}$ femur prosthesis

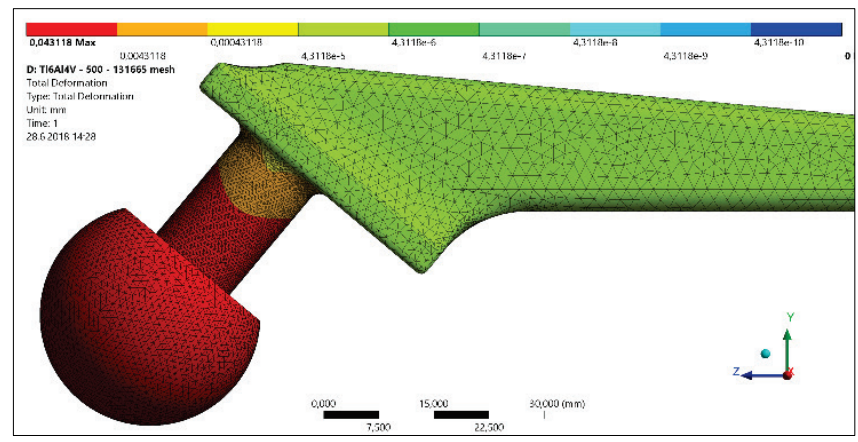

(a)

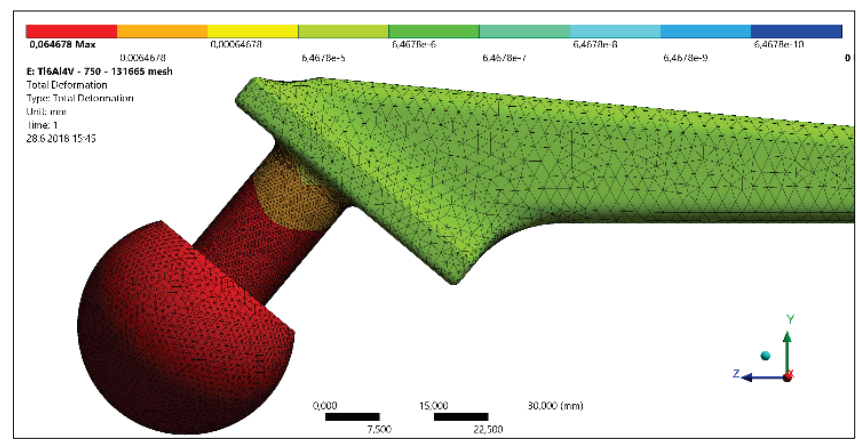

(b)

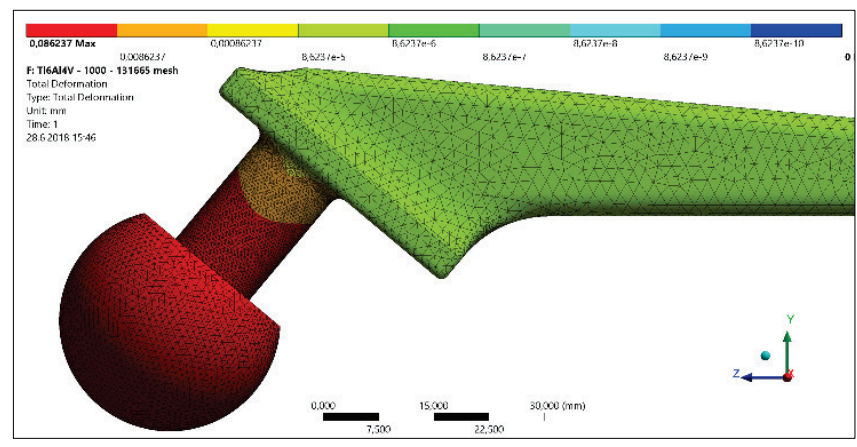

(c)

Figure 5 Total deformations under (a) $500 \mathrm{~N}$, (b) $750 \mathrm{~N}$, and (c) $1000 \mathrm{~N}$ loads on Ti6Al4V femur prosthesis 


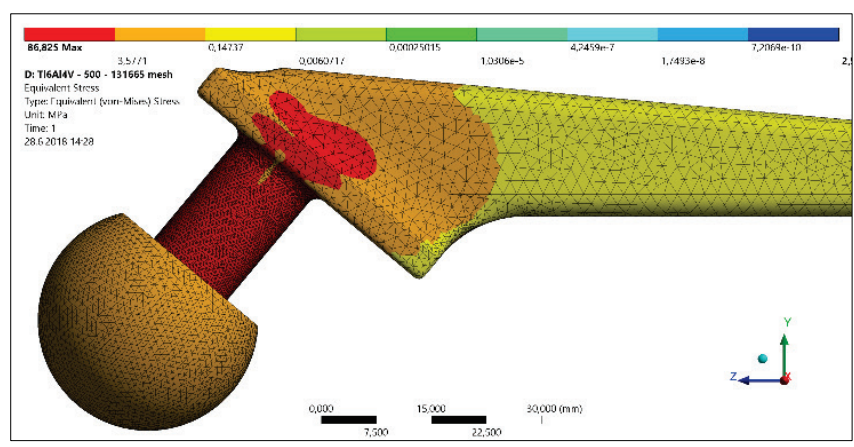

(a)

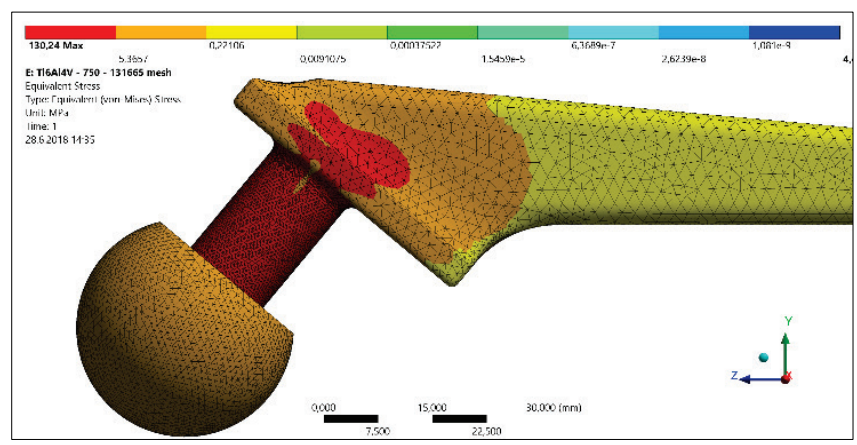

(b)

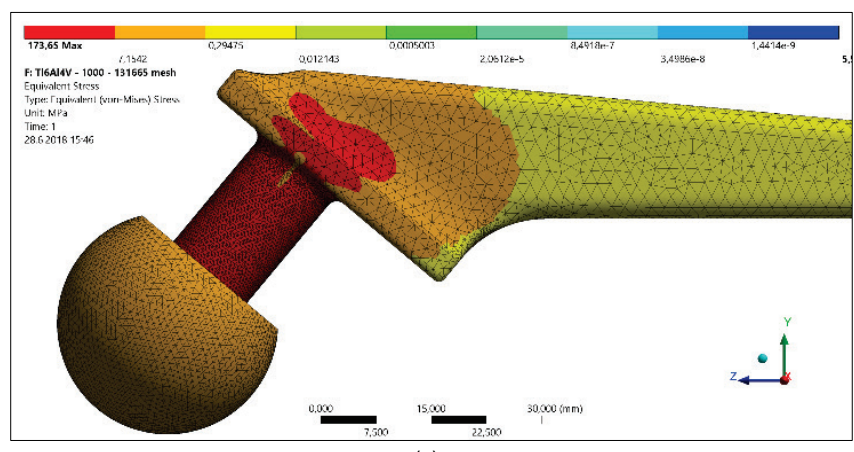

(c)

Figure 6 Equivalent stresses under (a) $500 \mathrm{~N}$, (b) $750 \mathrm{~N}$, and (c) $1000 \mathrm{~N}$ loads on Ti6Al4V femur prosthesis

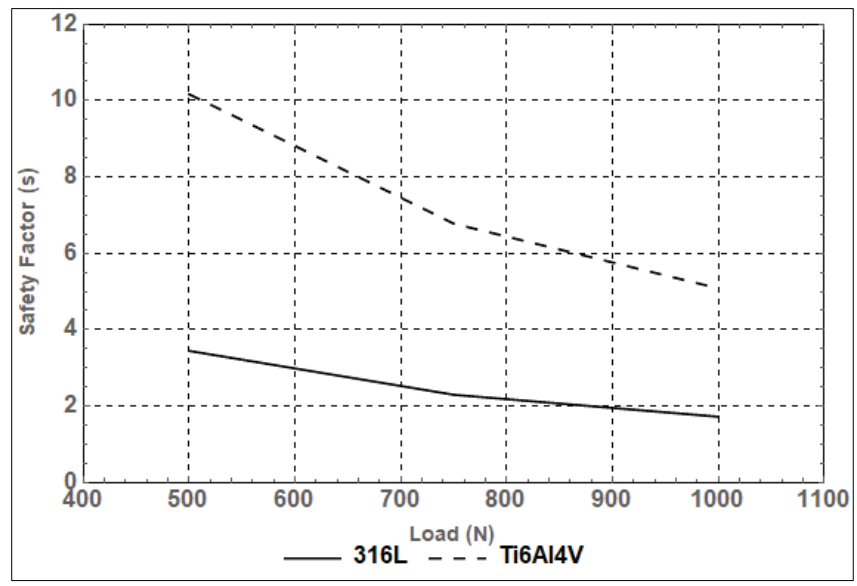

Figure 7 Maximum safety coefficients calculated according to yield strength of 316L stainless steel alloy and Ti6Al4V titanium alloy femoral prostheses

\section{DISCUSSIONS}

In biomaterials, mechanical properties are of great importance in terms of biocompatibility. In this study, human femoral prosthesis was modelled using $316 \mathrm{~L}$ stainless steel and Ti6Al4V titanium alloys and static analysis was performed under 500, 750 and $1000 \mathrm{~N}$ loads.

The results of the analyses are as follows:

1) With the femur implants whose body part is fixed in the bone, the region where the prosthesis body and neck join is the most critical region of the implant in terms of static resistance. This region is also critical in terms of fatigue due to constantly changing stresses during vital activities.

2) The load resulting from the weight of the human body causes the greatest spatial displacement at the head of the femoral implant. The largest deformation occurs in the neck region where stress is the highest.

3) The $316 \mathrm{~L}$ stainless steel alloy is mechanically biodegradable to replace the femur bone in overweight patients.

4) Ti6Al4V titanium alloy has very high mechanical biocompatibility even in patients with high piles.

\section{REFERENCES}

[1] Gür, A., \& Taşkın, M. (2004). Metalik biyomalzemeler ve biyouyum. Doğu Anadolu Bölgesi Araştırmaları Dergisi, 2, 106-113.

[2] Özalp, Y., \& Özdemir, N. (1996). Biyomateryaller ve biyouyumluluk. Ankara Üniversitesi Eczacılık Fakültesi Dergisi, 2, 57-72.

[3] Manivasagam, G., Dhinasekaran, A., \& Rajamanickam, A. (2010). Biomedical implants: corrosion and its prevention. Recent Patents on Corrosion Science, 2, 40-45. https://doi.org/10.2174/1877610801002010040

[4] Mudali, U. K., Sridhar, T. M., \& Raj, B. (2003). Corrosion of bio implants. Sadhana, 28(3-4), 601-637.

[5] Thomann, U. I., \& Uggowitzer, P. J. (2000). Wear-corrosion behavior of biocompatible austenitic stainless steels. Wear, 239, 48-58. https://doi.org/10.1016/S0043-1648(99)00372-5

[6] S. F. E., Shi, L., Guo, Z. G., \& Liu, W. M. (2015). The recent progress of tribological biomaterials. Biosurface and Biotribology, 1, 81-97. https://doi.org/10.1016/j.bsbt.2015.06.002

[7] Atilla, B. \& Alpaslan, M. (2002). Materyaller ve Enfeksiyon. TOTBID, 1(2): p. 111-113.

[8] Tuncer, S. \& Demirci, M. (2011). Dental materyallerde biyouyumluluk değerlendirmesi. Atatürk Üniv. Diş Hek. Fak. Der., 21(2), 141-149.

[9] Maharaj, P. S. R., Maheswaran, R., \& Vasanthanathan, A. (2013). Numerical analysis of fractured femur bone with prosthetic bone plates. Procedia Engineering, 64, 1242-1251. https://doi.org/10.1016/j.proeng.2013.09.204

[10] Nithin, K. K. C., Tandon, T., Silori, P., \& Shaikh, A. (2015). Biomechanical strees analysis of a human femur bone using ANSYS. Materials Today: Proceedings, 2, 2115-2120. https://doi.org/10.1016/j.matpr.2015.07.211

[11] Ebrahimi, H., Rabinovich, M., Vuleta, V., Zalcman, D., Shah, S., Dubov, A., Roy, K., Siddiqui, F. S., Schemitsch, E. H., Bougherara, H., \& Zdero, R. (2012). Biomechanical properties of an intact, injured, repaired and healed femur: An 
experimental and computational study. Journal of the Mechanical Behavior of Biomedical Materials, 16, 121-135. https://doi.org/10.1016/j.jmbbm.2012.09.005

[12] Özkan, A., Mutlu, İ., Atmaca, H., Buluç, L., Müezzinoğlu, M. S., \& Kişioğlu, Y. (2009). İnsan uyluk kemiğinin (femur) modellenmesi ve yük dağılım analizi. UMTS2009: Kıbrıs.

[13] Özkan, A. \& Atmaca, H. (2013). Femur boyun geometrisinin ve pelvis üzerindeki gerilme dağılımına etkisi. Düzce Tip Dergisi, 15(2), 1-6.

[14] Marangoz, S. (2009). Gelişimsel Koksa Vara, Türk Ortopedi ve Tramatoloji Birliği Derneği Dergisi, 8(3-4), 30-34.

[15] Hanumantharaju, H. G. \& Shivanand, H. K. (2009). Static analysis of bi-polar femur bone implant using FEA. Int. J. of Recent Trends in Engineering and Technology, 1(5), 118-121.

[16] Gervais, B., Vadean, A., Raison, M., \& Brochu, M. (2016). Failure analysis of a $316 \mathrm{~L}$ stainless steel femoral orthopedic implant. Case Studies in Engineering Failure Analysis, 5(6), 30-38. https://doi.org/10.1016/j.csefa.2015.12.001

[17] Davis, E. T., Olsen, M., Zdero, R., Papini, M., Waddell, J. P., \& Schemitsch, E. H. (2009). A biomechanical and finite element analysis of femoral neck notching during hip resurfacing. Journal of Biomechanical Engineering, 131(4), 041002-041002-8. https://doi.org/10.1115/1.3072889

[18] Spinelli, L. F., Macedo, C. A. S., Galia, C. R., Rosito, R., Schnaid, F., Corso, L. L., \& Iturrioz, I. (2012). Femoral stembone interface analysis of logical uncemented stem. Revista Brasileira de Engenharia Biomédica, 28(3), 238-247. https://doi.org/10.4322/rbeb.2012.031

[19] Aydin, I., Çetinel, H., Pasinli, A., \& Yuksel, M. (2013). Preparation of hydroxyapatite coating by using citric acid sodium citrate buffer system in the biomimetic procedure. Materials Testing, 58(2), 140-145.

https://doi.org/10.3139/120.110826

\section{Authors' contacts:}

Saim KURAL, Asst. Prof. Dr.

Mechanical Engineering Dept., Manisa Celal Bayar University MCBU Engineering Faculty AB-18 Yunusemre-Manisa Türkiye +902362012380

saimkural@gmail.com

Safiye IPEK AYVAZ, Lecturer

Corresponding Author

Turgutlu Vocational High School, Manisa Celal Bayar University

Belediye Fidanlık Tesisleri 45400 Turgutlu-Manisa Türkiye

+902363135502

s.ipekayvaz@gmail.com 